\title{
1 Modelling the risk of SARS-CoV-2 infection through PPE \\ 2 doffing in a hospital environment
}

Marco-Felipe King' ${ }^{1}$ Amanda M Wilson²*, Mark H. Weir ${ }^{3}$, Martín López-García ${ }^{4}$, Jessica

7 Proctor', Waseem Hiwar', Amirul Khan', Lovise A. Fletcher'1, P. Andrew Sleigh', Ian

8 Clifton$^{5}$, Stephanie J. Dancer6,7, Mark Wilcox 8 , Kelly A. Reynolds ${ }^{2}$ and Catherine J.

9 Noakes $^{1}$

11 ISchool of Civil Engineering, University of Leeds, Woodhouse Lane, Leeds, LS2 9JT, UK.

12 2Department of Community, Environment, and Policy, Mel and Enid Zuckerman

13 College of Public Health, University of Arizona, Tucson, AZ, USA

14 3Division of Environmental Health Sciences, The Ohio State University, Columbus, $\mathrm{OH}$,

15 United States of America

164 4School of Mathematics, University of Leeds, Woodhouse Lane, Leeds, LS2 9JT, UK.

17 5Department of Respiratory Medicine, St. James's Hospital, University of Leeds, Leeds,

18 UK

196 School of Applied Sciences, Edinburgh Napier University, Edinburgh, UK.

7 Department of Microbiology, Hairmyres Hospital, NHS Lanarkshire, G758RG, UK.

21 8Healthcare Associated Infections Research Group, Leeds Teaching Hospitals NHS

22 Trust and University of Leeds, Leeds, UK

$23 *$ Corresponding author 
medRxiv preprint doi: https://doi.org/10.1101/2020.09.20.20197368; this version posted September 23, 2020. The copyright holder for this preprint (which was not certified by peer review) is the author/funder, who has granted medRxiv a license to display the preprint in It is made available under a CC-BY 4.0 International license.

25 Keywords: SARS COV-2; COVID-19; PPE; surface contact transmission; quantitative

26 microbial risk assessment (QMRA); hospital infection model 
medRxiv preprint doi: https://doi.org/10.1101/2020.09.20.20197368; this version posted September 23 , 2020. The copyright holder for this preprint (which was not certified by peer review) is the author/funder, who has granted medRxiv a license to display the preprint in It is made available under a CC-BY 4.0 International license .

\section{Abstract}

Self-contamination during doffing of personal protective equipment (PPE) is a concern for healthcare workers (HCW) following SARS-CoV-2 positive patient care. Staff may subconsciously become contaminated through improper glove removal, so quantifying this risk is critical for safe working procedures. HCW surface contact sequences on a respiratory ward were modelled using a discrete-time Markov chin for: IV-drip care, blood pressure monitoring and doctors' rounds. Accretion of viral RNA on gloves during care was modelled using a stochastic recurrence relation. The HCW then doffed PPE and contaminated themselves in a fraction of cases based on increasing case load. The risk of infection from this exposure was quantified using a dose-response methodology. A parametric study was conducted to analyse the effect of: 1a) increasing patient numbers on the ward, 1b) the proportion of COVID19 cases, 2) the length of a shift and 3) the probability of touching contaminated PPE. The driving factors for infection risk were surface contamination and number of surface contacts. HCWs on a 100\% COVID-19 ward were less than 2-fold more at risk than on a $50 \%$ COVID ward (1.6\% vs $1 \%$ ), whilst on a $5 \%$ COVID-19 ward, the risk dropped to $0.1 \%$ per shift (sd=0.6\%). IV-drip care resulted in higher risk than blood pressure monitoring ( $1.1 \%$ vs $1 \% p<0.0001)$, whilst doctors' rounds produced a $0.6 \%$ risk (sd=0.8\%). Recommendations include supervised PPE doffing procedures such as the "doffing buddy" scheme, maximising hand hygiene compliance post-doffing and targeted surface cleaning for surfaces away from the patient vicinity.

\section{Importance}

Infection risk from self-contamination during doffing PPE is an important concern in healthcare settings, especially on a COVID-19 ward. Fatigue during high workload 
medRxiv preprint doi: https://doi.org/10.1101/2020.09.20.20197368; this version posted September 23, 2020. The copyright holder for this preprint (which was not certified by peer review) is the author/funder, who has granted medRxiv a license to display the preprint in

It is made available under a CC-BY 4.0 International license.

52 shifts may result in increased frequency of mistakes and hence risk of exposure.

53 Length of staff shift and number of COVID-19 patients on a ward correlate positively

54 with the risk to staff through self-contamination after doffing. Cleaning of far-patient

55 surfaces is equally important as cleaning traditional "high-touch surfaces", given

56 that there is an additional risk from bioaerosol deposition outside the patient zone(1). 
medRxiv preprint doi: https://doi.org/10.1101/2020.09.20.20197368; this version posted September 23 , 2020. The copyright holder for this preprint (which was not certified by peer review) is the author/funder, who has granted medRxiv a license to display the preprint in

It is made available under a CC-BY 4.0 International license .

\section{Introduction}

Severe acute respiratory syndrome coronavirus 2 (SARS-CoV-2) is an enveloped virus which has infected in excess of 10 million people to date and caused more than 700,000 deaths worldwide according to Johns Hopkins University's COVID-19 Dashboard (2). Inanimate objects known as fomites may host pathogens and have the potential to contribute to infection transmission in healthcare environments. This occurs in viral infection spread (3-5) including COVID-19 $(6,7)$. There appears to be similarity between persistence of SARS-CoV-1 and 2 on surfaces, with viable virus shown to be present for up to 72 hours (8). This allows an opportunity for exposure through hand-to-fomite contacts, especially if surfaces are heavily contaminated. Although personal protective equipment (PPE) such as gloves, gowns, and masks are worn to protect both patient and healthcare worker (HCW) from exposure, selfcontamination during PPE doffing processes $(9,10)$ poses risks to HCW and enables spread from one patient to another during multiple care episodes. SARS-CoV-2 has been detected on healthcare worker PPE (11) and in the environment of rooms where doffing occurs, providing evidence that errors in doffing could facilitate COVID-19 exposure and transmission.

While SARS-CoV-2 has been detected on PPE and patient surfaces, the relationship between viral RNA concentrations and risk of infection is still unknown(12). Quantitative microbial risk assessments (QMRA) involve the use of mathematical models to estimate doses of a pathogen and subsequent infection risk probabilities. Quantifying infection risk for any given dose can be used to guide intervention decision-making and have been used in other public health contexts,

81 such as in setting water quality standards (13). These typically rely on experimental

82 doses of a microorganism inoculated into healthy participants or mice models in a 83 known quantity. Whether they develop the infection can then be recorded(13). 
medRxiv preprint doi: https://doi.org/10.1101/2020.09.20.20197368; this version posted September 23 , 2020. The copyright holder for this preprint (which was not certified by peer review) is the author/funder, who has granted medRxiv a license to display the preprint in

It is made available under a CC-BY 4.0 International license .

84 QMRA modelling and surface contact models have been used to evaluate multiple

85 transmission pathways. The role of care-specific behaviours in environmental

86 microbial spread (14) includes the effect of glove use in bacterial spread from one

87 surface to another (15) and evaluating risk reductions through hand hygiene or

88 surface disinfection interventions (16-18). While a strength of QMRA is relating

89 environmental monitoring data to health outcomes, a common limitation has been

90 a lack of specific human behaviour data such as hand-to-face or hand-to-surface

91 contact sequences that result in dose exposures $(18,19)$. The use of the QMRA

92 modelling framework incorporating care type surface contact patterns before

93 potential self-contamination via PPE doffing will offer insight into infection risks per

94 shift, the importance of a doffing buddy and patient room surface cleaning

95 protocols.

The objective of this study is to relate SARS-CoV-2 concentrations on surfaces to

predicted risks of exposure and infection for a single healthcare worker over an 8-

hour shift and estimate the effects of doffing mistakes and number of care episodes per shift on infection risk per shift.

\section{Methodology}

This approach combines human behaviour and fomite-mediated exposure models for 19 hospital scenarios, for which concentrations of SARS-CoV-2 on hands and infection risk for a single shift are estimated for a registered nurse, an auxiliary nurse and a doctor. A control scenario was defined as a single episode of care with a SARS-CoV-2 positive individual with an $80 \%$ probability of self-contamination during doffing. Eighteen other scenarios covered 3 likelihoods of self-contamination: $5 \%$,

$10750 \%$, and $80 \%, \times 2$ case load conditions: 7 patients (low) vs. 14 patients (high) $\times 3$

108 probabilities of any given patient being COVID-19 positive: low (5\%), high (50\%), and 109 a 100\% COVID-19 positive ward. During low case load conditions, it was assumed 
medRxiv preprint doi: https://doi.org/10.1101/2020.09.20.20197368; this version posted September $23,2020$. The copyright holder for this preprint (which was not certified by peer review) is the author/funder, who has granted medRxiv a license to display the preprint in

perpetuity.
It is made available under a CC-BY 4.0 International license .

110 that the number of care episodes per shift would be less than for high load

111 conditions. The assumed number of patient care episodes when PPE is worn per shift

112 for low and high case load scenarios were 7 and 14, respectively, based on a

113 respiratory ward in a university teaching hospital in the UK. The low case load

114 estimate was based on communication with a UK NHS consultant, who tracked the

115 number of gowns used by healthcare workers over a week on a mixed COVID-19 8-

116 bed respiratory ward. All model parameters are described and reported in Table 1.

117 Per scenario, three simulations were run where sequences of hand-surface contacts

118 per care episode were care-specific (IV care, observational care, or doctors'

119 rounds).

120 Table 1. Model parameters and their distributions/point values

\begin{tabular}{|c|c|c|}
\hline Parameter & Distribution/Point Value & Reference \\
\hline $\begin{array}{l}\text { Surface contamination }\left(C_{R N A}\right) \\
\text { (RNA/ swabbed surface area) }\end{array}$ & $\begin{array}{c}\text { For infected patient scenarios } \\
\text { Surfaces: } \\
\text { Triangular ( } \min =3.3 \times 10^{3}, \text { mid }=2.8 \times 10^{4}, \text { max }=6.6 \times 10^{4} \text { ) } \\
\text { Patient: } \\
\text { Point estimate: } 3.3 \times 10^{3}\end{array}$ & (1) \\
\hline $\begin{array}{c}\text { Area of any given } \\
\text { surface }\left(A_{\text {surface }}\right) \\
\left(\mathrm{cm}^{2}\right)\end{array}$ & Triangular $(\min =5, \max =195, \mathrm{mid}=100)$ & Assumed \\
\hline $\begin{array}{l}\text { Fraction of RNA(infective) } \\
\text { assumed to be infectious }\end{array}$ & Uniform ( $\min =0.001, \max =0.1)$ & Assumed \\
\hline $\begin{array}{l}\text { Finger-to-surface transfer } \\
\text { efficiency }(\beta)\end{array}$ & $\begin{array}{l}\text { Normal (mean }=0.118, \mathrm{sd}=0.088 \text { ) } \\
\text { Left- and right-truncated at } 0 \text { and } 1 \text {, respectively }\end{array}$ & (5) \\
\hline $\begin{array}{l}\text { Surface-to-finger transfer } \\
\text { efficiency }(\lambda)\end{array}$ & $\begin{array}{l}\text { Normal (mean }=0.123, \mathrm{sd}=0.068 \text { ) } \\
\text { Left- and right-truncated at } 0 \text { and } 1 \text {, respectively }\end{array}$ & (5) \\
\hline $\begin{array}{l}\text { Finger-to-mouth transfer } \\
\text { efficiency }\left(T E_{H \rightarrow M}\right)\end{array}$ & $\begin{array}{l}\text { Normal (mean }=0.339, \mathrm{sd}=0.20 \text { ) } \\
\text { Left- and right-truncated at } 0 \text { and } 1 \text {, respectively }\end{array}$ & $(20,21)$ \\
\hline $\begin{array}{l}\text { Glove doffing self- } \\
\text { contamination transfer } \\
\text { efficiency }\end{array}$ & Uniform ( $\left.\min =3 \times 10^{-7}, \max =0.1\right)$ & (9) \\
\hline $\begin{array}{l}\text { T99 on Hands } \\
\text { (hours) }\end{array}$ & $\begin{array}{c}\text { Uniform } \\
(\min =1, \max =6)\end{array}$ & $(22,23)$ \\
\hline $\begin{array}{l}\text { T99 on surfaces } \\
\text { (hours) }\end{array}$ & $\begin{array}{c}\text { Uniform } \\
(\min =3, \max =120)\end{array}$ & (22) \\
\hline $\begin{array}{l}\text { Hand hygiene efficacy: } \\
\text { alcohol gel (logio reduction) }\end{array}$ & Uniform $(\min =2, \max =4)$ & (24) \\
\hline $\begin{array}{l}\text { Hand hygiene efficacy: soap } \\
\text { and water (log } 10 \text { reduction) }\end{array}$ & $\begin{array}{l}\text { Normal (mean }=1.62, \mathrm{sd}=0.12 \text { ) } \\
\text { Left-and right-truncated at } 0 \text { and } 6, \text { respectively }\end{array}$ & (25) \\
\hline
\end{tabular}


medRxiv preprint doi: https://doi.org/10.1101/2020.09.20.20197368; this version posted September 23, 2020. The copyright holder for this preprint (which was not certified by peer review) is the author/funder, who has granted medRxiv a license to display the preprint in

121
For in/out events:

Uniform ( $\min =0.10, \max =0.17$ )

For patient contacts:

Uniform ( $\min =0.04$, $\max =0.25$ )

For other surface contacts: Uniform $(\min =0.008, \max =0.25$ )

For hand-to-face contacts: Uniform ( $\min =0.008$, $\max =0.012$ )
(26)

$(19,27)$

Uniform ( $\min =445, \max =535)$

(28); This study $0.12,19.6$

$5.94 \pm 11.4$ $0.27,802.1$

Dose response curve parameter* $\beta$

*Dose response curve parameters are to be used in bootstrapped pairs. Mean \pm SD and minimum and maximum are provided to offer context as to the magnitude of these parameters. Bootstrapped pairs are available in supplemental data.

\section{Healthcare Worker Surface Contact Behaviour Sequences}

Fifty episodes of mock patient care were recorded overtly using videography in a respiratory ward side room at St James' Hospital, Leeds. Mock care was

undertaken by doctors and nurses with a volunteer from the research team to represent the patient. While these observations were carried out prior to COVID-19, it is assumed that patient care would be similar for any infected patient, including a COVID-19 patient. Ethical approval for the study was given by the NHS Health Research Authority Research Ethics Committee (London - Queen Square Research Ethics Committee), REF: 19/LO/0301. Sequences of surface contacts were recorded for three specific care types: IV drip insertion and subsequent care (IV, $n=17)$ conducted by registered nurses (RN); blood pressure, temperature and oxygen saturation measurement (Observations, $\mathrm{n}=20$ ) conducted by auxiliary nurses; and doctors' rounds (Rounds, $n=13$ ). Data from care were used to generate representative contact patterns to model possible sequences of surface contacts by HCWs in a single patient room. HCWs were found to touch surfaces in a non- 
medRxiv preprint doi: https://doi.org/10.1101/2020.09.20.20197368; this version posted September $23,2020$. The copyright holder for this preprint (which was not certified by peer review) is the author/funder, who has granted medRxiv a license to display the preprint in It is made available under a CC-BY 4.0 International license .

141 random manner, insofar that moving from one surface category to another has a

142 higher probability than a transition elsewhere. By assigning each surface category a

143 numerical value from 1 to 5, where Equipment = 1, Patient = 2, Hygiene

144 areas $=3$, Near-bed surfaces $=4$, and Far-bed surfaces $=5, \mathrm{HCW}$ sequential contact

145 of surfaces can be modelled in terms of weighted probabilities(14).

146 The movement of a HCW between surfaces is modelled using a discrete-time

147 Markov chain approach (14). Using defined weighted probabilities based on

148 observation of patient care, surface contact by HCW can be simulated based on

149 the property that, given the present state, the future and past surfaces touched are

150 independent. This is termed the Markov property (eq 1):

$$
P\left(X_{n+1}=i \mid X_{n}=j\right)
$$

Where $X_{n}$ represents the surface contacted in the $n^{\text {th }}$ event, $i$ and $j$ are two surfaces, and $P$ represents a conditional probability. This is then denoted $P_{j \rightarrow i}$ for ease of notation. For example, the probability if the HCW is currently touching the table that they will next touch the chair is $P_{\text {table } \rightarrow \text { chair }}$ and can be worked out by

156 counting the number of times this happens during care divided by the number of

157 times any surface is touched after the table(29).

Discrete-time Markov chains were fitted to observed care contact sequences using the "markovchainFit" function from the R package markovchain (version observational care sequences. States included "in" (entrance to the patient room),

163 "out" (exit from the patient room), contact with a far-patient surface, contact with a 164 near-patient surface, contact with a hygiene surface (e.g. tap, sink, soap or alcohol 165 dispenser), and contact with equipment. For each episode of care, the first event 166 was entrance into the patient room. All HCWs wore a gown, gloves, mask and face 
medRxiv preprint doi: https://doi.org/10.1101/2020.09.20.20197368; this version posted September 23, 2020. The copyright holder for this preprint (which was not certified by peer review) is the author/funder, who has granted medRxiv a license to display the preprint in It is made available under a CC-BY 4.0 International license .

167 shield when entering the room. The episode of care ended when an "out" event occurred.

\section{Exposure Model}

171 Accretion of microorganism on hands from surface contacts has been

172 demonstrated (14) to respond to a recurrence relationship which the concentration

173 On hands after the $\mathrm{n}^{\text {th }}$ contact, $C_{n}^{h}$, with the concentration on hands, $C_{n-1}^{h}$, and on

174 the surface involved, $C_{n-1}^{s}$, before the contact. See eq. 2.

$$
C_{n}^{h}=C_{n-1}^{h} e^{-k_{h} \Delta t}-S_{h}\left(\lambda C_{n-1}^{h} e^{-k_{h} \Delta t}-\beta C_{n-1}^{s} e^{-k_{s} \Delta t}\right)
$$

This is an adaptation of the pathogen accretion model (PAM) from King et al. concentration on hands for contact $n$ is equal to the previous concentration on the hand $\left(C_{n-1}^{h}\right)$ after adjusting for inactivation for the virus on the hand $\left(k_{h}\right)$ and surface $k_{s}$, minus the removal from the hand due to hand-to-surface transfer plus the gain to the hand due to surface-to-hand transfer. $\Delta t$ is the time taken for an episode of patient care and sampled from a uniform distribution of range 2-20minutes(31). Here, $\lambda$ and $\beta$ represent hand-to-surface and surface-to-hand transfer efficiencies respectively. The fraction of the total hand surface area $\left(S_{h}\right)$ is used to estimate how much virus is available for transfer given a concentration of number of viral particles $/ \mathrm{cm}^{2}$ on the gloved hand and surface.

\section{Estimating Inactivation on the Hand}

Sizun et al. (2000) evaluated the survival of human coronaviruses (HCOV) strains OC43 and 229E on latex glove material after drying. Within six hours, there was a $99 \%$ reduction in viral infectivity for HCoV-229E (22). For HCV-OC43, there was a 99\% (T99)

191 reduction viral infectivity within an hour (22). Harbourt et al. measured SARS CoV-2

192 inactivation on pig skin with virus remaining viable for up to 8 hours at $37^{\circ} \mathrm{C}$ (32). We 
medRxiv preprint doi: https://doi.org/10.1101/2020.09.20.20197368; this version posted September 23, 2020. The copyright holder for this preprint (which was not certified by peer review) is the author/funder, who has granted medRxiv a license to display the preprint in

It is made available under a CC-BY 4.0 International license .

193 therefore used a uniform distribution with a minimum of 1 hour and a maximum of 8

194 hours to estimate a distribution of $k_{h}$ inactivation rates.

195 Estimating Inactivation on Surfaces

196 The decay of the virus causing COVID-19 has been shown to vary under both

197 humidity and temperature but in contrast with previous findings(8), it appears that

198 surface material may not have a significant impact on decay rate(33). We therefore

199 take a conservative approach and use an averaged half-life $\tau$ estimate for stainless

200 steel and plastic-coated surfaces at $21-23^{\circ} \mathrm{C}(8)$ at $40 \%$ relative humidity; which are

$2015.63 \mathrm{~h}(95 \% \mathrm{Cl}=4.59-6.86 \mathrm{~h})$, and $6.81 \mathrm{~h}(95 \% \mathrm{Cl}=5.62-8.17 \mathrm{~h})$, respectively. We assume a

202 first order decay (eq 3) to estimate inactivation constant $k$ which we use here for

203 brevity instead of $k_{s}$ and $k_{h}$ in equation 2.

204

205

$C(t)=C_{0} e^{-k t}$

206

Surface viral concentration $C$ at any given time t then depends uniquely on initial

207

concentration $C_{0}$. Where the half-life $\tau$, is related to $\mathrm{k}$ by: $k_{s}=\log (2) / \tau$. Since hospital

rooms are made up of a combination of stainless steel and plastic surfaces, we have

taken the widest confidence interval as bounds when sampling from a uniform

210 distribution for inactivation rate $k_{s}$. Inactivation on gloves is assumed to be minimal

211 for the time-scale of a care episode (2-20minutes) (31).

212 Fractional Surface Area

213 For contacts with the door handle during "in" or "out" behaviors, a fractional

214 surface area was randomly sampled from a uniform distribution with a minimum of

2150.10 and a maximum of 0.17 for open hand grip hand-to-object contacts (26). For

216 contacts with the patient, a fractional surface area was randomly sampled from a

217 uniform distribution with a minimum of 0.04 and a maximum of 0.25 , for front partial 
medRxiv preprint doi: https://doi.org/10.1101/2020.09.20.20197368; this version posted September $23,2020$. The copyright holder for this preprint (which was not certified by peer review) is the author/funder, who has granted medRxiv a license to display the preprint in

It is made available under a CC-BY 4.0 International license.

218 finger or full front palm with finger contact configurations (26). For contacts with

219 other surfaces, fractional surface areas were randomly sampled from a uniform

220 distribution with a minimum of 0.008 and a maximum of 0.25 , spanning multiple

221 contact and grip types from a single fingertip up to a full palm contact (26).

222

\section{Transfer Efficiencies}

For contacts with surfaces other than the patient, a truncated normal distribution

with a mean of 0.123 and a standard deviation of 0.068 with maximum 1 and

minimum 0 was randomly sampled for surface-to-finger $(\lambda)$ transfer efficiencies based

227

on aggregated averages of influenza, rhinovirus and norovirus(5). For patient

228

contacts, transfer efficiencies were randomly sampled from a normal distribution

with a mean of 0.056 and a standard deviation of 0.032 , left- and right-truncated at

0 and 1 , respectively. The mean and standard deviation were informed by transfer

efficiencies for rhinovirus measured for direct skin to skin contact (34). Transfer

efficiencies from fingers to surfaces $(\beta)$ are assumed to be normally distributed with mean 0.118 and standard deviation $0.088(5)$.

\section{Surface Concentrations}

If the patient was assumed to be infected, surface contamination levels (RNA)

swab surface area) were sampled from a triangular distribution where the minimum

and maximum were informed by minimum and maximum contamination levels reported for surfaces in an intensive care unit ward (1). The median of these was used to inform the midpoint of the triangular distribution (1). For patient contacts, the concentration of virus detected on a patient mask was used as a point value $(3.3 \mathrm{x}$ 103RNA/swab surface area) (1). When a patient was not infected, it was assumed 
medRxiv preprint doi: https://doi.org/10.1101/2020.09.20.20197368; this version posted September $23,2020$. The copyright holder for this preprint (which was not certified by peer review) is the author/funder, who has granted medRxiv a license to display the preprint in

It is made available under a CC-BY 4.0 International license.

242 contacts with surfaces and with the patient would not contribute to additional

243 accretion of virus on gloved hands.

244 Surface areas to relate RNA/swabbed surface area to RNA/cm² were not

245 provided by Guo et al. (2020). While a typical sampling size is $100 \mathrm{~cm}^{2}$, it may be as

246 small as 10-25 $\mathrm{cm}^{2}$ (35-38) and in real-world scenarios, sampling surface areas may

247 be larger or smaller than these depending upon available surface area, ease of

248 access and the contamination magnitude expected. Since the surface areas of

249 these surfaces were not provided, a triangular distribution ( $\min =5, \max =195$,

250 mid=100) describing the surface area $\left(\mathrm{cm}^{2}\right)$ of surfaces sampled was used to

251 estimate RNA/ $\mathrm{cm}^{2}$. Not all detected RNA was assumed to represent infectious viral

252 particles. This is a conservative risk approach when utilizing molecular concentration

253 data in QMRA (39). Therefore, concentrations on surfaces $C^{S}$ (viable viral

254 particles $\left(\mathrm{cm}^{2}\right.$ ) were estimated by eq 4 ,

$$
C^{S}=\frac{C_{R N A}}{A_{\text {surface }}} \cdot \text { infective }
$$

256 where $C_{R N A}$ is the RNA/swabbed surface area, $A_{\text {surface }}$ is the surface area $\left(\mathrm{cm}^{2}\right)$ of

257 the surface, and infective is the fraction of RNA that relates to infective viral particles

258 (uniform $(\min =0.001, \max =0.1)$ ).

\section{Estimating Infection Risk}

For all scenarios, it was assumed the starting concentration on gloved hands for

261 the first episode of care was equal to 0 viral particles $/ \mathrm{cm}^{2}$. If gloves were doffed and

262 a new pair was donned in between care episodes, it was assumed the next episode

263 of care began with a concentration of 0 viral particles $/ \mathrm{cm}^{2}$ on the gloved hands.

264 After each care episode, a number was randomly sampled from a uniform

265 distribution with a minimum of 0 and a maximum of 1 . If this value was less than or

266 equal to the set probability of self-contamination during doffing, self-contamination 
medRxiv preprint doi: https://doi.org/10.1101/2020.09.20.20197368; this version posted September $23,2020$. The copyright holder for this preprint (which was not certified by peer review) is the author/funder, who has granted medRxiv a license to display the preprint in

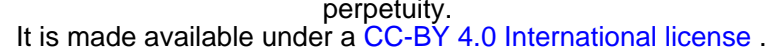

267 occurred, where the fraction of total virus transferred from the outer glove surface to

268 the hands was assumed to be uniformly distributed between $3 \times 10^{-5} \%$ and $10 \%$ (9).

269 There was then a 50/50 chance that either hands were washed or sanitized using

270 alcohol gel. If they washed their hands, a log 10 reduction was randomly sampled

271 from a normal distribution with a mean of 1.62 and a standard deviation of 0.12 ,

272 ( $\min =0$ and $\max =6$ ) (25). While these are not coronavirus-specific hand washing

273 efficacies they allow for a conservative estimate. If hand sanitizer was used, a log 10

274 reduction was randomly sampled from a uniform distribution with a minimum of 2

275 and a maximum of 4 (24).

276 To estimate a dose, an expected concentration on the hands after doffing and

277 hand hygiene was estimated, followed by an expected transfer to a facial mucosal

278 membrane during a single hand-to-nose contact after each patient care episode

279 (eq. 5).

280

$$
D=C_{h} \cdot T E_{H M} \cdot S_{m} \cdot A_{h} \cdot e^{-k_{h} \Delta t}
$$

There was a 50/50 chance that either the right or left hand was used for this hand-to-face contact. Here, the transfer efficiency $\left(T_{H \rightarrow M}\right)$ of the hand-to-nose contact was randomly sampled from a normal distribution with a mean of $33.90 \%$, and a standard deviation of $20 \%$ based on a viral surrogate(21). The fractional surface area of contact $\left(S_{m}\right)$ was assumed to equal one fingertip. To estimate this surface area, the minimum and maximum front partial fingertip fractional surface areas were divided by 5 to inform the minimum and maximum values of a uniform distribution (22). The surface area of a hand $\left(A_{h}\right)$ was randomly sampled from a uniform distribution with a minimum of $445 \mathrm{~cm}^{2}$ and a maximum of $535 \mathrm{~cm}^{2}$ (19) and is informed by values from the Environmental Protection Agency, USA's Exposure

291 Factors Handbook (27). The expected inactivation of virus during this contact 292 assumed a single second contact, and the final $k_{h}$ value used in the care episode 
medRxiv preprint doi: https://doi.org/10.1101/2020.09.20.20197368; this version posted September 23, 2020. The copyright holder for this preprint (which was not certified by peer review) is the author/funder, who has granted medRxiv a license to display the preprint in

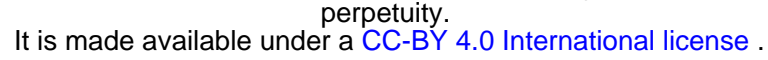

293 simulation was used. $\Delta t$ represents the time between doffing and touching the

294 mucosa. 10,000 parameter combinations are obtained for each care type scenario 295 in a Monte Carlo framework.

\section{Dose-Response}

297 Due to lack of dose-response curve data for SARS-CoV-2, an exact beta-

298 Poisson dose-response curve (40) was fitted to pooled data for SARS-CoV-1 and 299 HCoV 229E, assuming the infectivity of SARS-CoV-2 lies between the infectivity for 300 these two organisms. In eq 6., $F_{1}(\alpha, \alpha+\beta,-d)$ is the "Kummer confluent

301 hypergeometric function" and $P(d)$ is the probability of infection risk given dose: $d$ 302 (eq. 6) (40).

$$
P(d)=1-{ }_{1} F_{1}(\alpha, \alpha+\beta,-d)
$$

304 Ten-thousand bootstrapped pairs of $\alpha$ and $\beta$ were produced based on a maximum

305 likelihood estimation fit. For each estimated dose, an $\alpha$ and $\beta$ pair were randomly

306 sampled, and an infection risk was estimated with eq. 6. The infectious dose for $50 \%$

307 of infections to occur was between 5 and 100 infectious viral particles with a mean 308 of 30; the dose-response curve can be seen in Figure 1. 
medRxiv preprint doi: https://doi.org/10.1101/2020.09.20.20197368; this version posted September $23,2020$. The copyright holder for this preprint (which was not certified by peer review) is the author/funder, who has granted medRxiv a license to display the preprint in

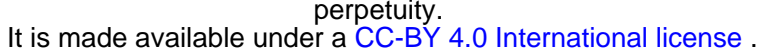

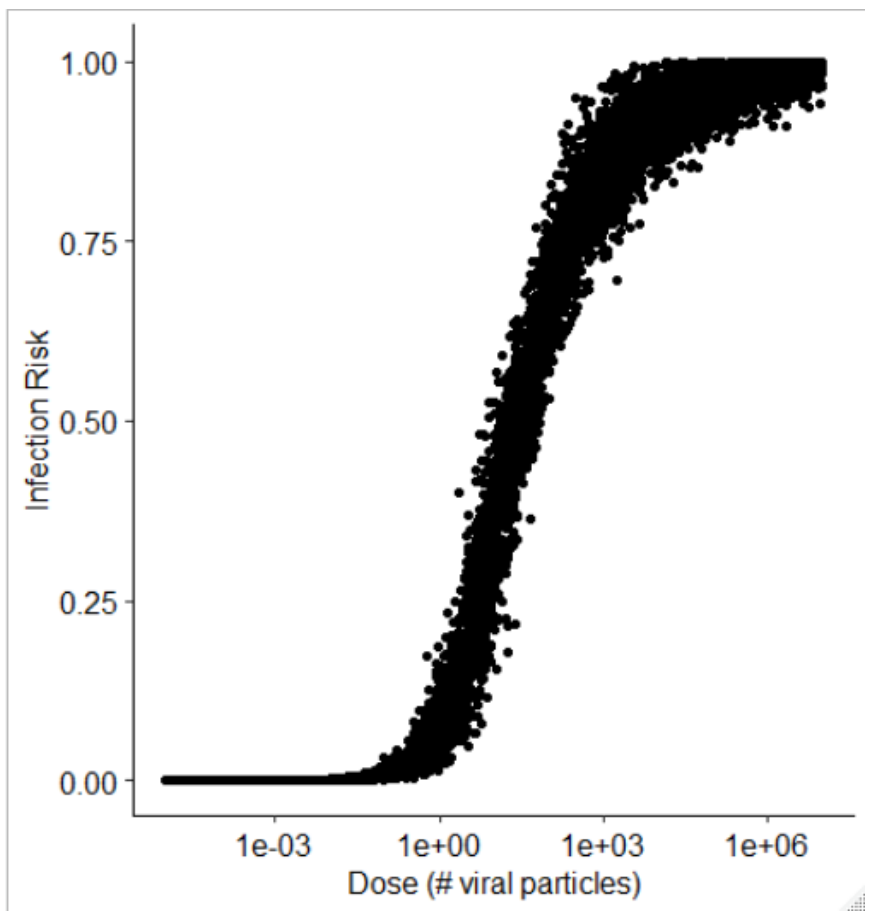

Figure 1 Dose-response risk curve for averaged SARS CoV-1 and Coronavirus 229E response.

\section{Sensitivity Analysis}

Spearman correlation coefficients were used to quantify monotonic

314 relationships between input variables and infection risk. This method has been used

315 in other QMRA studies to evaluate the relationship between model inputs and

316 outputs $(30,41,42)$. As not all relationships are monotonic, scatter plots of input

317 variables and associated infection risks were also investigated.

\section{Results}

319 Surface contact pattern predictions varied by care type. IV care resulted in the

320 highest number of surface contacts (mean=23, $s d=10$ ) per episode, whilst observational care and doctors' rounds had on average $14(\mathrm{sd}=7)$ and $20(\mathrm{sd}=6)$ pattern derived from the Markov chain prediction can be seen in Figure 2. 


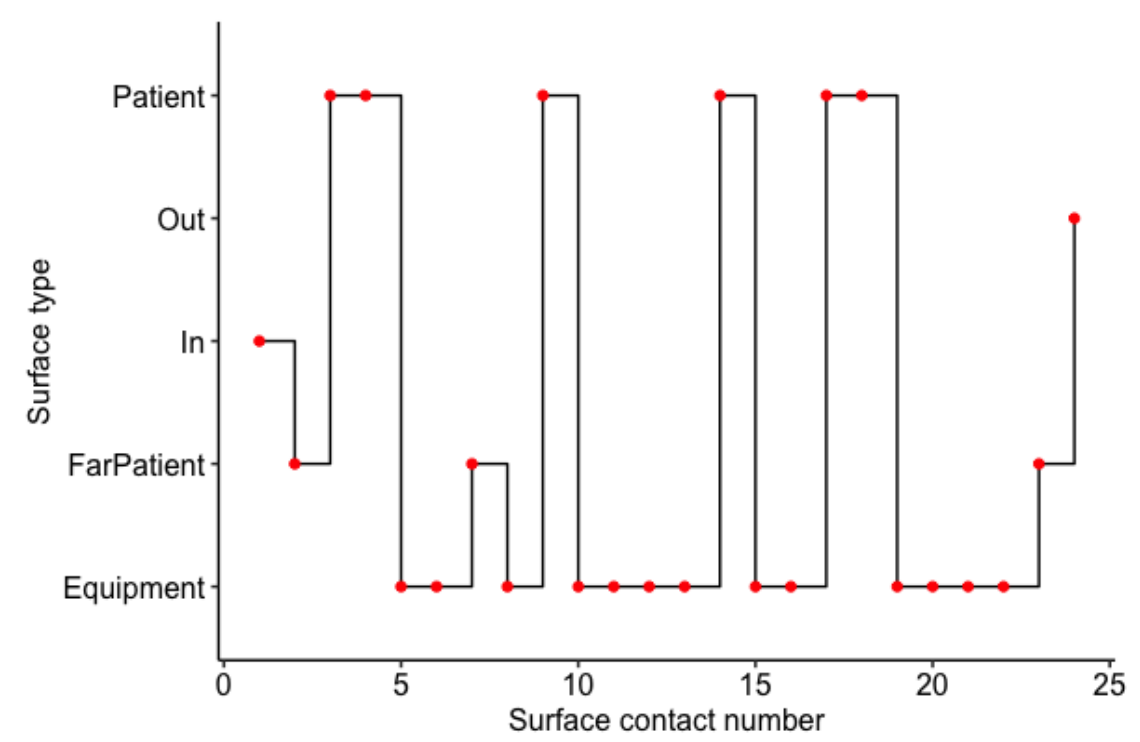

Figure 2 Stair plot of example HCW surface contacts during care

\section{Estimated Infection Risks}

328 After a care episode of any type, the risk of becoming infected from a single

329 facial contact ranged from 0 to $29 \%$ with a mean of $0.18 \%$. On average, IV care

330 provided the highest risk ( $1 \%$ per shift, $p<0.001)$ due to the number of surface

331 contacts (IV-drip care: $23 \pm 10$, Doctors' rounds: 14 \pm 7 and Observational care: $20 \pm 6$ ).

332 At a 7-patient load, regardless of COVID-19 prevalence, risk was $0.6 \%$ whilst doubling

333 patient capacity more than doubled the risk to $1.3 \%$ per shift. Figure 3 shows a bar

334 chart with standard deviations for care type, COVID-19 prevalence on the ward

335 and chance of self-contamination following a mistake during doffing. 


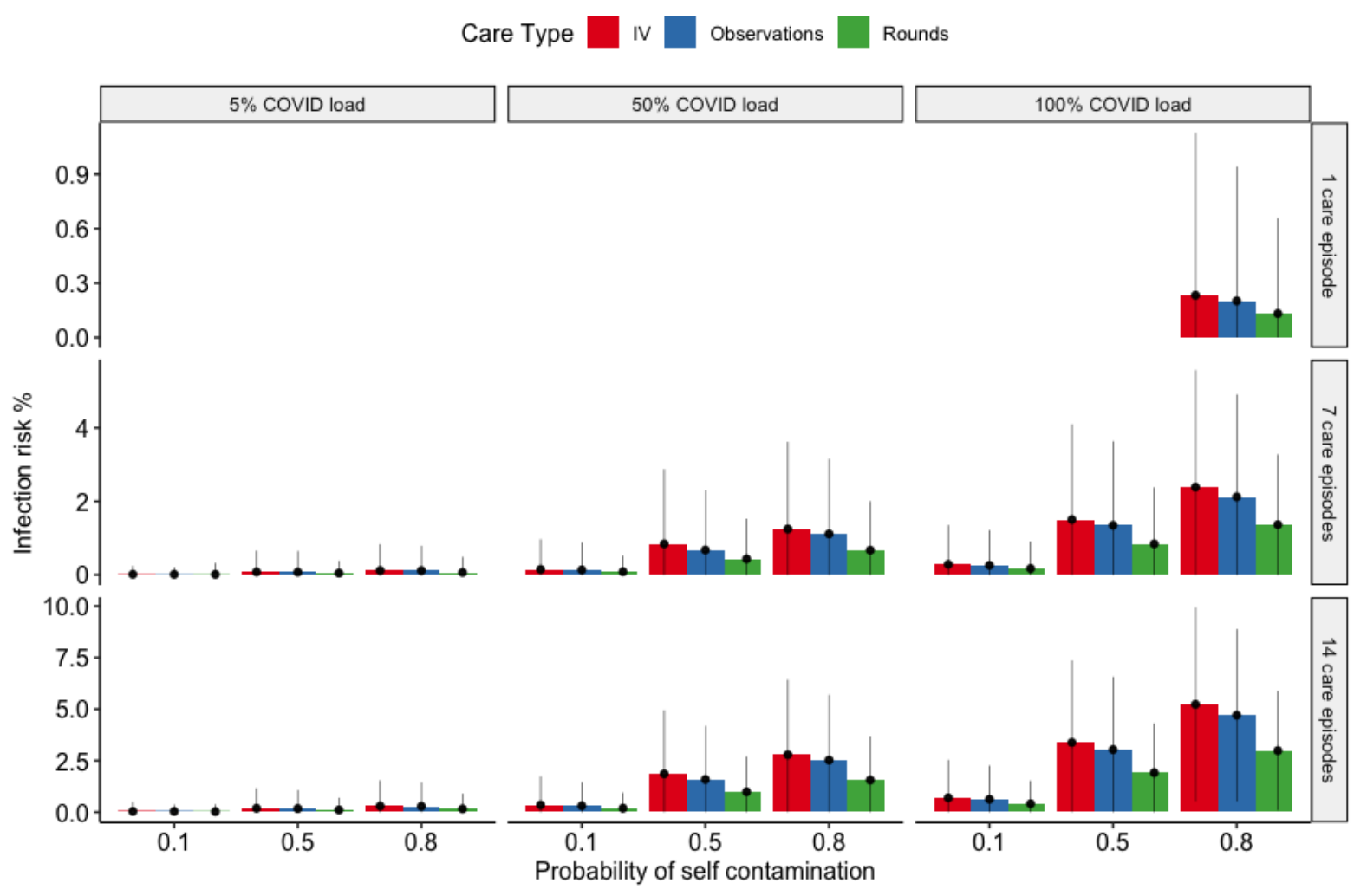

Figure 3: Bar chart showing infection risk \% per shift for IV, Observations and doctors' rounds for different COVID patient loads. Errorbars represent standard deviation of the mean.

341 linearly. HCWs on a 100\% COVID ward were less than a $2 x$ more at risk than on a $50 \%$ COVID ward (1.6\% vs $1 \%)$, whilst on a $5 \%$ COVID, the risk dropped to $0.1 \%$ per shift on average $(s d=0.6 \%)$

In terms of most important factor determining risk, Figure 4 shows two dimensional heatmaps of input parameters plotted against predicted infection risk to elucidate correlations. The stronger the correlation, the more influence that parameter has on

347 the output. Surface cleanliness was found to be the single most important factor in determining future risk, with hand-to-mouth/eyes/nose transfer efficiency only half as important (correlation coefficient $\rho=0.29$ vs $\rho=0.12$, respectively) (see Table 2). 
medRxiv preprint doi: https://doi.org/10.1101/2020.09.20.20197368; this version posted September 23, 2020. The copyright holder for this preprint (which was not certified by peer review) is the author/funder, who has granted medRxiv a license to display the preprint in

It is made available under a CC-BY 4.0 International license.

351 was run for half the surface bioburden. At double the cleaning frequency, the risk is

352 halved.

353 Table 2. Spearman correlation coefficients of input parameters with infection risk

\begin{tabular}{|c|c|}
\hline Parameter & Spearman Correlation Coefficient \\
\hline $\begin{array}{c}\text { Concentration on surfaces } \\
\text { (viral particles } / \mathrm{cm}^{2} \text { ) }\end{array}$ & 0.29 \\
\hline $\begin{array}{l}\text { Transfer efficiency to } \\
\text { mouth, eyes, or nose** }\end{array}$ & 0.12 \\
\hline $\begin{array}{l}\text { Transfer efficiency } \\
\text { surface to hand }\end{array}$ & 0.08 \\
\hline $\begin{array}{l}\text { Transfer efficiency } \\
\text { Hand to surface }\end{array}$ & 0.06 \\
\hline Inactivation constant for surfaces & 0.05 \\
\hline $\begin{array}{l}\text { Fraction of total hand surface area } \\
\text { in contact }\end{array}$ & -0.03 \\
\hline $\begin{array}{c}\text { Fraction of RNA relating to infectious } \\
\text { particles* }\end{array}$ & 0.03 \\
\hline $\begin{array}{l}\text { Fraction of total hand surface area } \\
\text { used in hand-to-face contact** }\end{array}$ & 0.03 \\
\hline Total hand surface area** & 0.02 \\
\hline Duration (seconds) & 0.02 \\
\hline Inactivation constant for hands & 0.01 \\
\hline $\begin{array}{c}\text { Alpha dose response curve } \\
\text { parameter }\end{array}$ & -0.01 \\
\hline $\begin{array}{c}\text { Beta dose-response curve } \\
\text { parameter }\end{array}$ & -0.002 \\
\hline
\end{tabular}

354

*The spearman correlation coefficient represents instances where contacts with surfaces that had non-zero concentrations were made **The spearman correlation coefficient represents instances in which these parameters were used in a simulation where a contaminated hand-to-face contact was made after doffing 

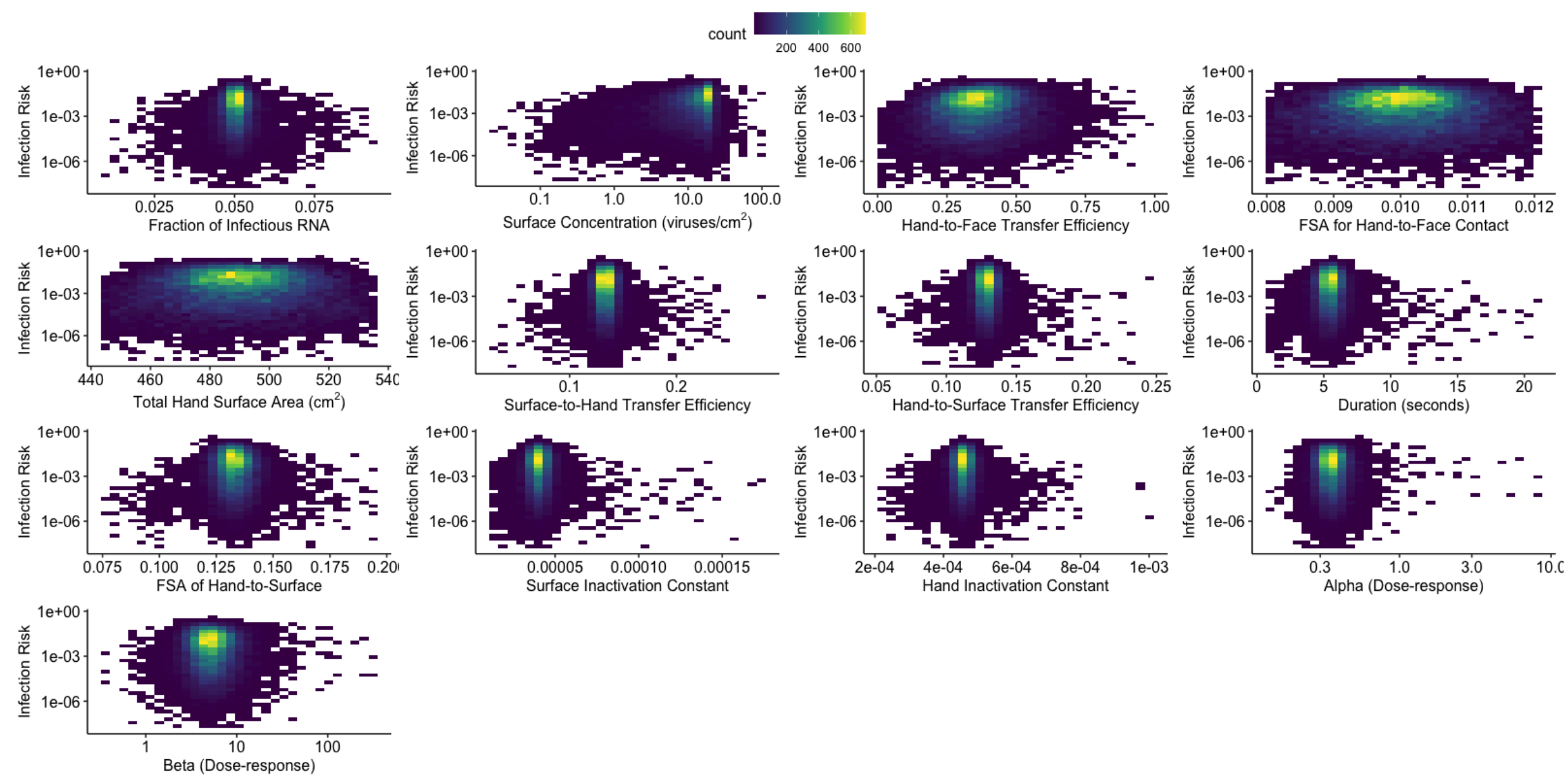

Figure 4 Heatmaps of input parameters plotted against estimated infection risks for scenarios in which doses were greater than zero. FSA= fractional surface area. Count represents the number of simulations resulting in a specified infection risk. 


\section{Discussion}

\section{Key Findings and Generalizability}

367 The model developed in this study indicates that risk of infection from mistakes

368 after doffing PPE is likely to be less than $1 \%$ for a single shift, even for nurses on $100 \%$ patient COVID-19 positive wards. Infection risks vary by care type as greater frequencies of surface contacts directly impact on viral loading on gloves and subsequent self-contamination exposures. The risk increases further if error rates in doffing are high and a high proportion of patients are COVID-19 positive (Figure 1), This highlights the importance of optimal hand hygiene, especially after PPE doffing. doffing mistake likelihood, highlighting the relevance of frequency of cleaning

377 regimes for managing risk. Halving the surface viral concentration decreased the

378 infection risk 2-fold. Studies have shown that microorganisms can be readily

379 transferred between touch sites in a healthcare environment by routine activities(43). Dispersion of respiratory droplets and aerosols may contaminate less frequently touched surfaces as well, particularly where the patient is undergoing treatment that generates aerosols such as continuous positive airway (CPAP) ventilation. Sampling in COVID wards suggests aerosol deposition is a contributor to surface contamination, as one study has reported deposition at a distance of $3 \mathrm{~m}$ from the patient(12). Previous experimental work aerosolising a bacteria in an airconditioned hospital room test-chamber showed that surfaces well outside the

387 patient zone can become contaminated with infectious material $(44,45)$. Since the observational study underlying the Markov chains reveals that at least $10 \%$ of staff contacts impact on such surfaces (excluding door handles), then current lists of 
medRxiv preprint doi: https://doi.org/10.1101/2020.09.20.20197368; this version posted September $23,2020$. The copyright holder for this preprint (which was not certified by peer review) is the author/funder, who has granted medRxiv a license to display the preprint in

It is made available under a CC-BY 4.0 International license.

390 high-touch surfaces(46) that had historically been prioritised for cleaning, may need

391 to be revised.

392 Regardless of the number of COVID-19 positive patients on a ward, notable

393 decreases in predicted infection risk were associated with less self-contamination

394 during doffing. For example, for scenarios involving all COVID-19 patients, the mean

395 infection risk for $10 \%$ probability of self-contamination while doffing was $0.4 \%$, while

396 the mean infection risk for an $80 \%$ probability of self-contamination while doffing was

397 more than a $420 \%$ increase at $2.1 \%$ (Table 1). This emphasizes the importance of

398 adequate training for PPE use. Less risk of self-contamination will decrease

399 transmission risks, potentially through a doffing buddy. PPE can be an effective

400 strategy for mitigating exposure if proper doffing techniques are used. In addition to

401 training, improvements in PPE design that enhance safety and expediency of

402 doffing may lower self-contamination rates and therefore improve PPE as a

403 mitigation strategy (47). For example, fasteners or ties on gowns/masks were

404 identified as "doffing barriers," because it was unclear whether these were to be

405 untied and there were difficulties in reaching these ties. Self-contamination due to

406 gowns and masks were not specifically addressed in this model. It is possible that

407 self-contamination during doffing of items other than gloves could increase

408 potential risks due to incorrect doffing. Shortages of PPE have changed normal

409 practice where PPE is worn on a sessional basis rather than renewed for each

410 patient. This means less doffing and potentially less auto-contamination but may

411 increase the risk of virus transfer within the unit.

412 In addition to the importance of safe and proper doffing, the results from this

413 computational study also emphasize the importance of surface decontamination

414 and environmental monitoring strategies. The concentration of virus on surfaces was

415 the most influential parameter on infection risk, which is consistent with other surface 
medRxiv preprint doi: https://doi.org/10.1101/2020.09.20.20197368; this version posted September 23,2020 . The copyright holder for this preprint (which was not certified by peer review) is the author/funder, who has granted medRxiv a license to display the preprint in

It is made available under a CC-BY 4.0 International license.

416 transmission risk studies (30). Whilst SARS-CoV-2 RNA has been detected on surfaces,

417 one limitation to a molecular approach is the lack of information regarding

418 infectivity. In a recent study by Zhou et al. (2020), no surface samples demonstrated

419 infectivity. However, it was noted that the concentrations of SARS-CoV-2 on surfaces

420 were below the current detection limits for culture methodologies (38). While there

421 are known relationships between cycle threshold values and probabilities of

422 detecting viable virus in a sample $(48,49)$, it is necessary to know what fraction of

423 detected genome copies relate to viral particles for QMRAs. More data are needed

424 to better understand how molecular concentrations, even concentrations below

425 detection limits, relate to infectivity and subsequent infection risk.

\section{Limitations}

The model in this study only evaluates a surface transmission route while in

reality, risks posed to healthcare workers are due combined exposure pathways: air,

droplet, person-to-person, and surface transmission. As the model only evaluates

surface transmission, these infection risks are likely to be an underestimate of the

total risk incurred by healthcare workers over an entire shift. In a study of healthcare

432 workers in a facility in Wuhan, China, 1.1\% (1 10/9684) were COVID-19 positive (50).

433 According to CDC, of 428,295 healthcare personnel for which data were available,

$43420 \%(84,035 / 428,295)$ were COVID-19 cases $(51)$. However, it is not known how many

435 shifts were associated with these infection rates. Additionally, we assumed that

436 wards with non-COVID-19 patients did not have SARS-CoV-2 contamination on

437 surfaces, due to lack of data on SARS-CoV-2 surface contamination beyond COVID-

43819 wards or patient rooms. There is potential for asymptomatically infected

439 healthcare workers to contribute environmental contamination, especially when

440 considering the relatively long shedding durations for asymptomatic infections (52). 
medRxiv preprint doi: htps://doi.org/10.1101/2020.09.20.20197368; this version posted September 23,2020 . The copyright holder for this preprint (which was not certified by peer review) is the author/funder, who has granted medRxiv a license to display the preprint in It is made available under a CC-BY 4.0 International license .

441 Infected healthcare workers and environmental contamination could be

442 considered in future extensions of this model.

443 The fact that the proportions of healthcare workers with COVID-19 discussed

444 above are much larger than the infection risks estimated suggest that other

445 transmission routes could drive additional HCW cases. This would include more

446 transmission through airborne routes, or $\mathrm{HCW}$ to $\mathrm{HCW}$ transmission by asymptomatic

447 cases outside the COVID-19 care environment (53). However, while there continues

448 to be disagreement over the contribution of each route to overall risk, transmission

449 routes influence each other, making them all significant in healthcare environments.

450 For example, surfaces can become contaminated due to deposition of aerosolized

451 virus. Viruses can later be resuspended from surfaces, contributing to air

452 contamination. Future work should extend current models with a multi-exposure

453 pathway approach. This will advance not only our understanding of SARS-CoV-2

454 transmission but the transmission of pathogens in built environments as a whole.

455 Finally, a dose-response curve informed by SARS-CoV-1 and HCoV 229E data

456 was utilized, due to lack of SARS-CoV-2-specific dose-response data. We suggest

457 that this therefore is a conservative estimate. Despite limitations related to dose-

458 response, the conclusions from the estimated doses were consistent with insights

459 from infection risk estimates. Increases in probability of contamination between care

460 episodes related to increases in dose and most notably, for scenarios in which more

461 than $5 \%$ of patients had COVID-19 (Figure 3, Figure S1).

\section{Conclusion}

463 We propose a model for predicting risk of infection to healthcare workers from

464 self-contamination during doffing of personal protective equipment over a single

465 shift. The model estimates the quantity of SARS-CoV-2 virus accretion on gloved 
medRxiv preprint doi: https://doi.org/10.1101/2020.09.20.20197368; this version posted September 23, 2020. The copyright holder for this preprint (which was not certified by peer review) is the author/funder, who has granted medRxiv a license to display the preprint in

It is made available under a CC-BY 4.0 International license .

466 hands for three types of non-aerosol-generating procedures: IV-care, observations

467 and doctors' rounds. Once doffing was in progress, staff self-contaminated a

468 fraction of the times based on patient-load fatigue. Three COVID-19 positive patient

469 scenarios (5\%, 50\% and 100\% COVID-19 patients) were investigated amounting to a

470 total of 30,000 parameter combinations allowing us to conduct a "what-if"

471 parametric study and sensitivity analysis. Surface viral concentration was found to

472 be more than twice as important as any other factor whereby highlighting the

473 importance of time-appropriate cleaning. Transfer efficiency from finger to nose was

474 of secondary importance, although hand hygiene following doffing is highly

475 recommended. A doffing buddy could help reduce mistakes regardless of patient

476 numbers and hence is also recommended. Whilst risk from this type of self-

477 contamination sits at around $1 \%$ per healthcare worker shift, this highlights that the

478 procedures, if carried out correctly, are generally safe. It is accepted that other

479 routes of transmission will play a significant role in infection propagation.

\section{Conflicts of Interest}

$481 \quad$ None to declare

\section{Acknowledgements}

The authors thank Marc P. Verhougstraete, PhD; Christina Liscynesky, MD for their

shared expertise and experience that contributed to the development of the

modelled scenarios in this study. This research is funded by the Engineering and

486 Physical Sciences Research Council, UK: Healthcare Environment Control,

487 Optimisation and Infection Risk Assessment (https://HECOIRA.leeds.ac.uk)

488 (EP/P023312/1). M. López-García was funded by the Medical Research Council, UK

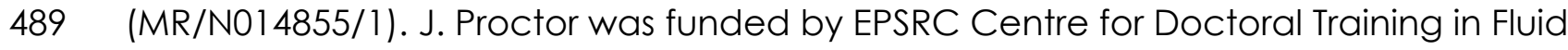

490 Dynamics at Leeds (EP/L01615X/1). Under a Creative Commons Zero v1.0 Universal 
medRxiv preprint doi: https://doi.org/10.1101/2020.09.20.20197368; this version posted September 23, 2020. The copyright holder for this preprint (which was not certified by peer review) is the author/funder, who has granted medRxiv a license to display the preprint in

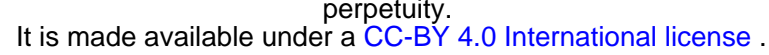

491 license (CC-BY), code can be accessed at: https://github.com/awilson12/surface-

References

494 1. Guo Z-D, Wang Z-Y, Zhang S-F, Li X, Li L, Li C, Cui Y, Fu R-B, Dong Y-Z, Chi X-Y, and Surface Distribution of Severe Acute Respiratory Syndrome Coronavirus 2 in Hospital Wards, Wuhan, China, 2020. Emerg Infect Dis 26.

2. Johns Hopkins University. COVID-19 Dashboard by the Center for Systems Science and Engineering.

3. Boone SA, Gerba CP. 2007. Significance of fomites in the spread of respiratory and enteric viral disease. Appl Environ Microbiol 73:1687-1696.

4. Otter JA, Donskey C, Yezli S, Douthwaite S, Goldenberg SD, Weber DJ. 2016. Transmission of SARS and MERS coronaviruses and influenza virus in healthcare settings: The possible role of dry surface contamination. J Hosp Infect 92:235250.

5. Kraay ANM, Hayashi MAL, Hernandez-Ceron N, Spicknall IH, Eisenberg MC, Meza R, Eisenberg JNS. 2018. Fomite-mediated transmission as a sufficient pathway: a comparative analysis across three viral pathogens. BMC Infect Dis 18:540.

510 6. Santarpia JL, Rivera DN, Herrera V, Morwitzer MJ, Creager H, Santarpia GW, 511 Crown KK, Brett-Major D, Schnaubelt E, Broadhurst MJ, Lawler J V, Reid SP,

512 Lowe JJ. 2020. Transmission Potential of SARS-CoV-2 in Viral Shedding

513 Observed at the University of Nebraska Medical Center. medRxiv

$514 \quad 2020.03 .23 .20039446$.

515 7. Ye G, Lin $H$, Chen L, Wang S, Zeng Z, Wang W, Zhang S, Rebmann T, Li Y, Pan Z, 
medRxiv preprint doi: https://doi.org/10.1101/2020.09.20.20197368; this version posted September $23,2020$. The copyright holder for this preprint (which was not certified by peer review) is the author/funder, who has granted medRxiv a license to display the preprint in

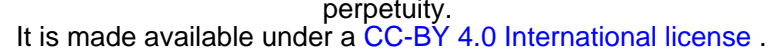

517 of the SARS-CoV-2 in healthcare premises: An urgent call for protection for

518 healthcare workers. medRxiv 2020.03.11.20034546.

519 8. van Doremalen N, Bushmaker T, Morris DH, Holbrook MG, Gamble A,

520 Williamson BN, Tamin A, Harcourt JL, Thornburg NJ, Gerber SI, Lloyd-Smith JO,

521 de Wit E, Munster VJ. 2020. Aerosol and Surface Stability of SARS-CoV-2 as

522 Compared with SARS-CoV-1. N Engl J Med.

523 9. Casanova LM, Erukunuakpor K, Kraft CS, Mumma JM, Durso FT, Ferguson AN,

524 Gipson CL, Walsh VL, Zimring C, Dubose J, Jacob JT, Control D, Program PE.

525 2018. Assessing Viral Transfer During Doffing of Ebola-Level Personal Protective

526 Equipment in a Biocontainment Unit. Clin Infect Dis 66:945-949.

527 10. Tomas ME, Kundrapu S, Thota P, Sunkesula VCK, Cadnum JL, Mana TSC,

528 Jencson A, O'Donnell M, Zabarsky TF, Hecker MT, Ray AJ, Wilson BM, Donskey

529 CJ. 2015. Contamination of health care personnel during removal of personal

530 protective equipment. JAMA Intern Med 175:1904-1910.

531 11. Ong SWX, Tan YK, Chia PY, Lee TH, Ng OT, Wong MSY, Marimuthu K. 2020. Air,

Surface Environmental, and Personal Protective Equipment Contamination by

Severe Acute Respiratory Syndrome Coronavirus 2 (SARS-CoV-2) from a

Symptomatic Patient. JAMA - J Am Med Assoc 3-5.

535 12. Liu Y, Ning Z, Chen Y, Guo M, Liu Y, Gali NK, Sun L, Duan Y, Cai J, Westerdahl D,

536 Liu X, Xu K, Ho K fai, Kan H, Fu Q, Lan K. 2020. Aerodynamic analysis of SARS-

$537 \quad$ CoV-2 in two Wuhan hospitals. Nature 582:557-560.

538 13. WHO. 2016. Quantitative Microbial Risk Assessment: Application for Water Safety Management. WHO Press 187.

540 14. King M-FM-F, Noakes CJ, Sleigh P a. 2015. Modelling environmental

541 contamination in hospital single and four-bed rooms. Indoor Air 25:694-707.

542 15. King MM-F, López-García M, Atedoghu KP, Zhang N, Wilson AM, Weterings M, 
medRxiv preprint doi: https://doi.org/10.1101/2020.09.20.20197368; this version posted September 23, 2020. The copyright holder for this preprint (which was not certified by peer review) is the author/funder, who has granted medRxiv a license to display the preprint in

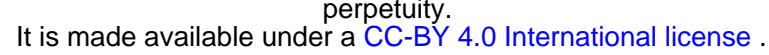

Hiwar W, Dancer SJS, Noakes CJC, Fletcher LA LA, López-García M, Atedoghu KP, Zhang N, Wilson AM, Weterings M, Hiwar W, Dancer SJS, Noakes CJC, Fletcher LA LA. 2020. Bacterial transfer to fingertips during sequential surface contacts with and without gloves. Indoor Air Accepted.

16. Wilson AM, Reynolds KA, Sexton JD, Canales RA. 2018. Modeling surface disinfection needs to meet microbial risk reduction targets. Appl Environ Microbiol 84:1-9.

17. Wilson AM, Reynolds KA, Jaykus LA, Escudero-Abarca B, Gerba CP. 2020. Comparison of estimated norovirus infection risk reductions for a single fomite contact scenario with residual and nonresidual hand sanitizers. Am J Infect Control 48:538-544..

18. Wilson AM, Reynolds KA, Canales RA. 2019. Estimating the effect of hand hygiene compliance and surface cleaning timing on infection risk reductions with a mathematical modeling approach. Am J Infect Control Article 47:14531459.

19. Beamer PI, Plotkin KR, Gerba CP, Sifuentes LY, Koenig DW, Reynolds KA. 2015. Modeling of human viruses on hands and risk of infection in an office workplace using micro-activity data. J Occup Environ Hyg 12:266-75.

20. Rusin P, Maxwell S, Gerba C. 2002. Comparative surface-to-hand and fingertip-to-mouth transfer efficiency of gram-positive bacteria, gramnegative bacteria, and phage. J Appl Microbiol 93:585-92.

564 21. Lopez GU, Gerba CP, Tamimi AH, Kitajima M, Maxwell SL, Rose JB. 2013. Transfer efficiency of bacteria and viruses from porous and nonporous fomites to fingers under different relative humidity conditions. Appl Environ Microbiol. 
medRxiv preprint doi: https://doi.org/10.1101/2020.09.20.20197368; this version posted September $23,2020$. The copyright holder for this preprint (which was not certified by peer review) is the author/funder, who has granted medRxiv a license to display the preprint in It is made available under a CC-BY 4.0 International license .

acquired infections. J Hosp Infect 46:55-60.

570

571

572

573

574

575

576

577

578

579

580

581

582

583

584

585

586

587

588

589

590

591

592

593

594

23. Warnes SL, Little ZR, Keevil CW. 2015. Human Coronavirus 229E Remains Infectious on Common Touch Surface Materials. MBio 6:1-10.

24. Kampf G, Todt D, Pfaender S, Steinmann E. 2020. Persistence of coronaviruses on inanimate surfaces and its inactivation with biocidal agents. J Hosp Infect 104:246-251.

25. Girou E, Loyeau S, Legrand P, Oppein F, Brun-Buisson C. 2002. Efficacy of handrubbing with alcohol based solution versus standard handwashing with antiseptic soap: randomised clinical trial. BMJ 325:362-362.

26. AuYeung W, Canales RA, Leckie JO. 2008. The fraction of total hand surface area involved in young children's outdoor hand-to-object contacts. Environ Res 108:294-299.

27. U.S. Environmental Protection Agency. 2011. Exposure Factors Handbook 2011 Edition (EPA/600/R-09/052F). Washington, DC.

28. Watanabe T, Bartrand TA, Weir MH, Omura T, Haas CN. 2010. Development of a dose-response model for SARS coronavirus. Risk Anal 30:1129-1138.

29. Jinadatha C, Villamaria FC, Coppin JD, Dale CR, Williams MD, Whitworth R, Stibich M. 2017. Interaction of healthcare worker hands and portable medical equipment: A sequence analysis to show potential transmission opportunities. BMC Infect Dis 17:1-10.

30. Julian TR, Canales RA, Leckie JO, Boehm AB. 2009. A model of exposure to rotavirus from nondietary ingestion iterated by simulated intermittent contacts. Risk Anal 29:617-632.

31. King M-F, Noakes CJ, Sleigh PA, Bale S, Waters L. 2016. Relationship between healthcare worker surface contacts, care type and hand hygiene: An observational study in a single-bed hospital ward. J Hosp Infect 94:48-51. 
medRxiv preprint doi: https://doi.org/10.1101/2020.09.20.20197368; this version posted September $23,2020$. The copyright holder for this preprint (which was not certified by peer review) is the author/funder, who has granted medRxiv a license to display the preprint in

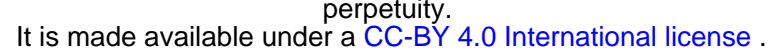

595 32. Harbourt DE, Haddow AD, Piper AE, Bloomfield H, Kearney BJ, Fetterer D, Gibson K, Minogue T. 2020. Modeling the Stability of Severe Acute Respiratory Syndrome Coronavirus 2 (SARS-CoV- 2) on Skin, Currency, and Clothing. medRxiv.

33. Biryukov J, Boydston JA, Dunning RA, Yeager JJ, Wood S, Reese AL, Ferris A, Miller D, Weaver W, Zeitouni NE, Phillips A, Freeburger D, Hooper I, RatnesarShumate S, Yolitz J, Krause M, Williams G, Dawson DG, Herzog A, Dabisch P, Wahl V, Hevey MC, Altamura LA. 2020. Increasing Temperature and Relative Humidity Accelerates Inactivation of SARS-CoV-2 on Surfaces. mSphere 5:1-9.

34. Pancic F, Carpentier DC, Came PE. 1980. Role of infectious secretions in the transmission of rhinovirus. J Clin Microbiol 12:567-571.

607

35. Whiteley GS, Glasbey TO, Fahey PP. 2016. A suggested sampling algorithm for use with ATP testing in cleanliness measurement. Infect Dis Heal 21:169-175.

36. Public Health England. 2017. Detection and enumeration of bacteria in swabs Microbiol Stand Method 4.

37. Margas E, Maguire E, Berland CR, Welander F, Holah JT. 2013. Assessment of the environmental microbiological cross contamination following hand drying with paper hand towels or an air blade dryer. J Appl Microbiol 115:572-582.

38. Zhou AJ, Otter JA, Price JR, Cimpeanu C, Garcia M, Kinross J, Boshier PR, Mason S, Bolt F, Alison H, Barclay WS. 2020. Investigating SARS-CoV-2 surface and air contamination in an acute healthcare setting during the peak of the COVID-19 pandemic in London. medRxiv 1-24. 
medRxiv preprint doi: https://doi.org/10.1101/2020.09.20.20197368; this version posted September 23, 2020. The copyright holder for this preprint (which was not certified by peer review) is the author/funder, who has granted medRxiv a license to display the preprint in It is made available under a CC-BY 4.0 International license .

40. Xie G, Roiko A, Stratton H, Lemckert C, Dunn PK, Mengersen K. 2017. Guidelines for use of the approximate beta-Poisson dose-response model. Risk Anal $37: 1388-1402$.

41. Canales RA, Wilson AM, Sinclair RG, Soto-Beltran M, Pearce-Walker J, Molina M, Penny M, Reynolds KA. 2019. Microbial study of household hygiene conditions and associated Listeria monocytogenes infection risks for Peruvian women. Trop Med Int Heal 24:899-921.

42. Canales RA, Reynolds KA, Wilson AM, Fankem SLM, Weir MH, Rose JB, AdElmaksoud S, Gerba CP. 2019. Modeling the role of fomites in a norovirus outbreak. J Occup Environ Hyg 16:16-26.

43. Rawlinson S, Ciric L, Cloutman-Green E. 2020. COVID-19 pandemic - let's not forget surfaces. J Hosp Infect 5-6.

44. King M-F, Noakes CJ, Sleigh PA, Camargo-Valero MA. 2013. Bioaerosol deposition in single and two-bed hospital rooms: A numerical and experimental study. Build Environ 59:436-447.

45. King MF, Camargo-Valero MA, Matamoros-Veloza A, Sleigh PA, Noakes CJ. 2017. An effective surrogate tracer technique for $S$. aureus bioaerosols in a mechanically ventilated hospital room replica using dilute aqueous lithium chloride. Atmosphere (Basel) 8.

46. Huslage K, Rutala WA, Gergen MF, Ascp MT, Sickbert-bennett EE, Weber DJ. 2013. Microbial Assessment of High- , Medium-, and Low-Touch Hospital Room Surfaces and Low-Touch Hospital Room Surfaces 34:21 1-212.

47. Baloh J, Reisinger HS, Dukes K, Da Silva JP, Salehi HP, Ward M, Chasco EE, Pennathur PR, Herwaldt L. 2019. Healthcare Workers' Strategies for Doffing Personal Protective Equipment. Clin Infect Dis 69:S192-S198.

48. Bullard J, Dust K, Funk D, Strong JE, Alexander D, Garnett L, Boodman C, Bello 
medRxiv preprint doi: https://doi.org/10.1101/2020.09.20.20197368; this version posted September 23, 2020. The copyright holder for this preprint (which was not certified by peer review) is the author/funder, who has granted medRxiv a license to display the preprint in It is made available under a CC-BY 4.0 International license .

A, Hedley A, Schiffman Z, Doan K, Bastien N, Li Y, Van Caeseele PG, Poliquin G. 2020. Predicting infectious SARS-CoV-2 from diagnostic samples. Clin Infect Dis $1-18$.

650

49. La Scola B, Le Bideau M, Andreani J, Hoang VT, Grimaldier C. 2020. Viral RNA load as determined by cell culture as a management tool for discharge of SARS-CoV-2 patients from infectious disease wards. Eur J Clin Microbiol Infect Dis 39:1059-1061.

50. Lai X, Wang M, Qin C, Tan L, Ran L, Chen D, Zhang H, Shang K, Xia C, Wang S, Xu S, Wang W. 2020. Coronavirus Disease 2019 (COVID-2019) Infection Among Health Care Workers and Implications for Prevention Measures in a Tertiary Hospital in Wuhan, China. JAMA Netw open 3:e209666.

51. Centers for Disease Control and Prevention. 2020. Coronavirus Disease 2019 (COVID-19): Cases in the U.S.

52. Long Q-X, Tang X-J, Shi Q-L, Li Q, Deng H-J, Yuan J, Hu J-L, Xu W, Zhang Y, Lv Finfections. Nat Med 1-5.

664 53. Sikkema RS, Pas SD, Nieuwenhuijse DF, Toole ÁO, Verweij J, Linden A Van Der, Chestakova I, Schapendonk C, Koopmans MPG. 2020. Articles COVID-19 in health-care workers in three hospitals in the south of the Netherlands: a crosssectional study 3099:1-8. 